\title{
ARTYKUŁY
}

Klio. Czasopismo poświęcone dziejom Polski i powszechnym

PL ISSN 1643-8191, t. 58 (2)/2021, s. 93-107

(c) (1) $\Theta$

TOMASZ ŁADOŃ ${ }^{*}$

\section{Between Marius, Cinna and Sulla The role of the Valerii Flacci in the Roman Republic in the eighties of the 1st century BC}

\begin{abstract}
Valerii Flacci was one of the most influential families in Rome in the first two decades of the 1 st century BC. Cicero called them a nobilissima familia, while they themselves were the apple of the Roman aristocracy and were perceived as the best citizens (optimi cives). During the First Civil War, they were initially associated with the Marian camp. L. Valerius Flaccus (consul of $100 \mathrm{BC}$ ) acted as princeps senatus since 86 BC, and his cousin, also L. Valerius Flaccus was consul suffectus in $86 \mathrm{BC}$, after the death of C. Marius. The brother of L. Valerius Flaccus, Caius, consul of 93 BC, during the reign of Cinna in Rome was the governor of Spain for many years, and later of Transalpine Gaul too. It is known that Valerii Flacci wanted to reach a compromise between Sulla and the Marian camp, and when their efforts failed, they opted for Sulla.

Despite the significant role Valerii Flacci played in the Republic, their activities remain overshadowed by other figures of that period. Also, their switch to the Sulla camp in the memory of the ancients was quite poorly recorded, especially when compared with the publicity of the transition of figures such as Metellus Pius, Pompeius or Crassus to Sulla's side. The author of the presented paper will attempt to coax Valerii Flacci out of the shadows of history, examine the genesis of their defection to the Sulla camp and determine the role they played in this camp in the initial period of Sulla's dictatorship.
\end{abstract}

Keywords: Valerii Flacci, Sulla, Marians, Cinanns, Sullans, First Civil War

* Jan Długosz University in Czestochowa, Institute of History, Al. Armii Krajowej 36a, 42-200 Częstochowa, tladon@wp.pl, ORCID 0000-0003-0481-0484. 
T he Valerii Flacci were a patrician line of one of the most noble Roman families, the gens Valeria. They probably already distinguished themselves from the family in the 4th century BC; nonetheless, the first fully confirmed member of the line was L. Valerius Flaccus, the consul of 261, who - during the First Punic War - waged campaigns on Sicilia. ${ }^{1}$ During the next two centuries, the Valerii Flacci wound consistently - roughly one time per generation - attain the top office in the state. Moreover, not only were they censors, but they also held the highest priestly offices, and two of them had the privilege to sit in the Roman Senate as princeps senatus. ${ }^{2}$ Thus, they were a part of the elite among the authorities of the Roman Republic, and Cicero described the Valerii Flacci as a nobilissima familia. ${ }^{3}$ Only in the second half of the 2 nd century BC did the importance of the line decrease.

In the eighties of the 1 st century BC the Valerii Flacci were prominent, and three more members of this line attained the highest dignities in the country. They played an important role in the battle for power that was unfolding at that time between C. Marius and L. Cornelius Sulla. At the beginning, they were related to the Cinno-Marian regime, but they were gradually withdrawing from it so that they could stand at Sulla's side. The aim of this article is to show the evolution of the Valerii Flacci's position in the conflict between the Sullans and Marians, and to determine their role in the political changes in the Roman Republic in the eighties of the 1st century BC.

Exploration of this issue is possible due to the preserved sources. Admittedly, the activity of the Valerii Flacci was never of primary interest to ancient writers; nonetheless, thanks to the political duties and other tasks confided to them, there is relatively generous information about this line in the historical sources. The importance of these materials and their credibility differs, however. The accounts of Appian of Alexandria and Plutarch of Chaeronea carry the most weight, but one needs to remember that they

1 T. R. S. Broughton, The magistrates of the Roman Republic, vol. 1, New York 1951, p. 204.

2 These people were L. Valerius Flaccus (cos. 195) in the year 184 (Liv. 39.52.1-2) and L. Valerius Flaccus (cos. 100) in the year 86 (Liv, Per. 83). See G. V. Sumner, The orators in Cicero's Brutus: Prosopography and chronology, Toronto 1972, p. 83.

3 Cic., Flacc. 81. 
were sourced from the works of writers involved in the political battle in the eighties of the 1st century BC, and so these materials are tainted by propaganda. ${ }^{4}$ The data provided by Plutarch and Appian supplement small pieces of information from the works of other authors. ${ }^{5}$

Contemporary researchers have been examining the actions of the Valerii Flacci line either in a holistic fashion, ${ }^{6}$ or in the context of the political situation in the Roman Republic in the eighties. ${ }^{7}$ The topic of the famous lex Valeria, who appointed Sulla the dictator, ${ }^{8}$ has been broadly raised too. As far as I know, the circumstances whereby the Valerii Flacci defected to Sulla's side are yet to be written about.

At the end of the 2 nd century BC, the Valerii Flacci became more politically active, mainly due to the fact they became involved with Caius Marius, who was in a position of power in the Roman Republic at that time. It is worth mentioning that it was not the first time that members of this patrician line stood by the side of the gifted homo novus. In 195 BC, L. Valerius Flaccus held the consular office along with M. Porcius Cato

4 This is mainly about the propaganda of Sulla, since he wrote his Commentarii, in which he conveyed his vision of the First Civil War. This piece of work has not survived, but still it was an important source for Appian and Plutarch. See: P. Scholz, Sullas commentariieine literarische Rechtfertigung. Zu Wesen und Funktion der autobiographischen Schriften in der späten Römischen Republik, in: Formmen römischer Geschichtsschreibung von den Anfängen bis Livius - Gattungen, Autoren, Kontexte, eds. U. Eigler et al., Darmstadt 2003, pp. 172-195; C. Smith, Sulla's memoirs, in: The Lost Memoirs of Augustus and the Development of Roman Autobiography, eds. C. Smith, A. Powell, Swansea 2009, pp. 65-85.

5 Memnon, FGrH 3B, 353, 34; Diod. 38, 8, 1; Strab. 13, 1, 27, 594c; Liv., Per. 82; Vell 2, 23, 2; 24, 1; Cass. Dio 30-35 fr. 105, 1-5; Auct., Vir. Ill. 70, 1; Oros. 6, 2, 9. See T. R. S. Broughton, The magistrates..., vol. 2, pp. 18-19, 53, 59, 64.

6 About gens Valeria see F. Münzer, De Gente Valeria, Oppolle 1891. About the line of Flacci see L. Hayne, The Valerii Flacci - a family in decline, "Ancient Society" 1978, vol. 9, pp. 223-233.

7 See e.g.: H. Bennet, Cinna and his times, Menasha 1924, pp. 40-50; M. Lovano, The age of Cinna: Crucible of late republican Rome, Stuttgart 2002, pp. 55, 72-73, 76, 79-81, 98-99.

8 H. Bellen, Sullas Brief an den Interrex L. Valerius Flaccus: Zur Genese der sullanischen Diktatur, "Historia" 1975, Bd. 15, pp. 555-569; F. J. Vervaet, The Lex Valeria and Sulla's Empowerment as Dictator (82-79 BCE), "Cahiers Glotz" 2004, vol. 15, pp. 37-84. 
Censorius, and in $184 \mathrm{BC}$ they were both the censors. ${ }^{9}$ It is not fully known when the cooperation of the Valerii Flacci and Marius began, ${ }^{10}$ nonetheless, in the year 100 BC, L. Valerius Flaccus and the buster of Cimbri and Teutones were the consuls together, and Publius Rutilius Rufus (quoted by Plutarch) stated, with a certain dose of pettiness, that Marius treated Flaccus not like a consul equal to him, but rather as if he were his subordinate. ${ }^{11}$ The biographer from Chaeronea also mentions that Marius, thanks to his electoral bribery, influenced the election of the officials in $100 \mathrm{BC}$, which may suggest that he influenced Flaccus's appointment of his workmate. ${ }^{12}$ There is little known about the actions that Flaccus took during his consular office; ancient writers only mentioned his collaboration with Marius while fighting with the tribune of the plebs, L. Appuleius Saturninus. ${ }^{13}$

In 97 BC, L. Valerius Flaccus along with Marcus Antonius were censors. ${ }^{14}$ Both were in favour of Marius and acted in favour him. It is likely that the six-time consul, who could not be a censor himself, made sure that these two candidates were chosen. ${ }^{15}$ There are presumptions that dur-

9 T. R. S. Broughton, The magistrates..., vol. 1, pp. 339, 374-375. See also E. Badian, Waiting for Sulla, JRS 1962, vol. 52, p. 56.

10 Ernst Badian (Studies in Greek and Roman history, Oxford 1964, pp. 86-87) at the beginning dated their collaboration a long time before their shared consulship and stated that L. Valeriuvs Flaccus owed his acquittal to the trial for which his ex-questor M. Aurelius Scarus built a case for in 104, but due to G.V. Sumner's criticism (The orators..., pp. 80-82) he backed off with his stance. See E. Badian, Three non-trials in Cicero. Notes on the text, prosopography and chronology of divinatio in Caecilium 63, "Klio" 1984, vol. 66, pp. 298-299. Cf. M. C. Alexander, Trials in the late Roman Republic, 149 BC to 50 BC, Toronto-Buffalo-London 1990, p. 47.

11 Plut., Mar. 28, 6. About L. Valerius Flaccus see F. Münzer, L. Valerius Flaccus, in: Real-Encyclopädie der classischen Altertumswissenschaft (further RE), Bd. 15, 2 Reihe, Stuttgart 1955, col. 22-25.

12 It is likely that Marius influenced the outcome of the election the year before too, since Manius Aquilius, who was involved with him, got to be the consul. See R. J. Evans, Gaius Marius. A political biography, Pretoria 1994, p. 87.

13 Cic., Rab. Perd. 20, 27. See H. Appel, Kontrowersje wokót senatus consultum ultimum. Studium z dziejów późnej republiki rzymskiej, Toruń 2013, p. 128.

14 T. R. S. Broughton, The magistrates..., vol. 2, New York 1952, p. 6-7.

15 E. Badian, Caepio and Norbanus: Notes on the decade 100-90 BC, "Historia" 1957, Bd. 6, p. 333. 
ing the preparation of the lustrum the censors registered a lot of Latin and Italic allies of Marius as Roman citizens. ${ }^{16}$ They also voted the tribune of the plebs, Duronius, out of his office. He called for abolition of the bill against luxuries (lex sumptuaria). ${ }^{17}$ Apart from this, they once again appointed M. Aemilius Scaurus as the princeps senatus. ${ }^{18}$ Any other actions of L. Valerius Flaccus from this period are unknown. In the years to come, the consul of the year $100 \mathrm{BC}$ disappeared from the sources; ancient writers do not mention his participation in the Social War at all; nor do they talk about his reaction to Sulla's march on Rome in 88 BC, although it is safe to say that he condemned this deed of the soon-to-be dictator. L. Valerius Flaccus during his protests was not aggressive enough for Sulla to designate him as one of the twelve people announced as enemies of the state (hostes publici), which could mean that he was not seen as a member of Marius' factio at that time in Rome. ${ }^{19}$ After Sulla's departure to the East in $87 \mathrm{BC}$, L. Valerius Flaccus undoubtedly seconded the consul L. Cornelius Cinna, and in the year $86 \mathrm{BC}$ he was nominated for the reputable office of princeps senatus by the censors. ${ }^{20}$

Apart from previously mentioned L. Valerius Flaccus, the consul of $100 \mathrm{BC}$, in the nineties of the 1st century BC two of his cousins, brothers

16 According to Gruen (Political prosecutions in 90's BC, "Historia" 1966, Bd. 15, p. 40) there is no hard evidence that the censors were involved in this operation, but Badian (Caepio..., p. 333) claims, that passed in 95 (so only 2 years after Antonius and Flaccus were the censors) lex Licinia Mucia, which established the criminal tribunal judging foreigners falsely claiming to be Roman citizens, can indicate that the censors of the year 97 added to the list of citizens a lot of allies.

17 Val. Max. 2.9.5. It is probably about lex Licinia. See J. Rominkiewicz, O rzymskich ustawach ograniczajacych wydatki na organizację uczt (Makrobiusz, Saturnalia 3, 17), "Acta Universitatis Wratislaviensis. Prawo" 2016, vol. 321, pp. 46-47.

18 Ascon., In Scaur. 18, 22 C.

19 App., BC 1, 60, 271. See T. R. S. Broughton, The magistrates..., vol. 2, p. 40 and the analysis of the list of hostes, carried out by B. R. Katz (The First Fruits of Sulla March, "L’Antiquité Classique" 1975, vol. 44, pp. 105-115). According to this researcher, it was the members of factio of Marius who were condemned and prosecuted.

20 Liv., Per. 83. See: P. Willems, Le Sénat de la République romaine, vol. 1, LouvainParis-Berlin 1885, p. 394; F. X. Ryan, Rank and participation in the republican Senate, Stuttgart 1998, p. 191. 
Caius and Lucius, were also participating in the Roman politics. It is not known to what extent L. Valerius, who was more experienced and deserving, helped his relatives, but it can be speculated that he used his influence to help them into their next governmental offices.

The older of the two brothers mentioned above was Caius Valerius Flaccus. There is little confirmed information about him. Likely in $96 \mathrm{BC}$ (or slightly earlier), ${ }^{21}$ he was the preator (as the praetor urbanus). ${ }^{22}$ After that, in $95 \mathrm{BC}$, he was the governor of Asia, ${ }^{23}$ so that in $93 \mathrm{BC}$ he could finally (along with Marcus Herennius) hold the highest office in the country. ${ }^{24}$ Already during his consulship, or immediately after its end, Caius was sent to Spain to pacify one of the Celtiberian uprisings. ${ }^{25}$ It was likely that he was assigned two of the Spanish provinces to govern, and in $86 \mathrm{BC}$, or in $85 \mathrm{BC}$ the latest, he also got Gallia Narbonensis, and probably also Gallia Cisalpina to administer. ${ }^{26}$

The younger one of the two brothers, Lucius, who is often confused with his older namesake cousin, ${ }^{27}$ in $99 \mathrm{BC}$ or $98 \mathrm{BC}$ became the curule aedile. ${ }^{28}$ Around $96 \mathrm{BC}$ (or $95 \mathrm{BC}$ ), he held the praetorship, after which he - like his brother - administered the Asia province, maybe in $95 \mathrm{BC}$ or 94 BC. ${ }^{29}$ After coming back to Italy, for a few years he was not given the consular office (it is not known if he was even trying for it) and only in $86 \mathrm{BC}$, after the death of Marius, did he become consul suffectus along with L. Cornelius Cinna, so he managed to hold the highest office in the state. ${ }^{30}$ Nothing about his actions during the Social War, nor about his reaction to

21 T. R. S. Broughton, The magistrates..., vol. 3, Atlanta 1986, p. 211; T. Corey Brennan, The praetorship in the Roman Republic, Oxford 2000, p. 552.

22 Cic., Balb. 55.

23 T. Corey Brennan, The praetorship..., p. 442.

24 T. R. S. Broughton, The magistrates..., vol. 2, p. 14.

25 App., Ib. 100.

26 T. R. S. Broughton, The Magistrates..., vol. 3, Atlanta 1986, p. 211. E. Badian, Waiting..., p. 59.

27 B. R. Katz, The siege of Rome in 87 BC, CPh 1976, vol. 71, p. 330.

28 T. R. S. Broughton, The magistrates..., vol. 2, p. 1; vol. 3, p. 212; B. R. Katz, The siege..., p. 330.

29 Cf. T. Corey Brennan, The praetorship..., p. 554.

30 T. R. S. Broughton, The magistrates..., vol. 2, p. 53. 
Sulla's march on Rome was noted by ancient writers. However, it can be suspected that his stance on these events was like his older cousin's. Some researchers identify Lucius Valerius Flaccus as the commander of the cavalry garrison stationed in Ostia, who gave the harbour away to Marius in $87 \mathrm{BC} .{ }^{31}$ Other researchers go even further, claiming that these credits contributed to the appointment of Lucius for the consulship. ${ }^{32}$ It seems like such pondering on this topic goes too far. On the other hand, it is known that Lucius was married to Baebia, a daughter of a certain not precisely identified Q. Baebius. However, we cannot draw too many conclusions from this piece of information, because the Baebia - a plebeian family with consular traditions reaching back even to the 2 nd century $\mathrm{BC}$ - were on both sides in the conflict between Marius and Sulla. ${ }^{33}$

Ancient authors wrote about another rise in the political career of the Valerii Flacci that took place in 86 BC, when L. Valerius Flaccus, the consul of 100 BC, was appointed by censors M. Perperna and L. Marcius Philippus as princeps senatus, and his younger namesake cousin was chosen for the consular office, replacing Caius Marius, who died in January of 86 BC. ${ }^{34}$ If we add that probably in the year 86 BC C. Valerius Flaccus's governance was extended to Gallia Narbonensis, then the rise of the Valerii Flacci is thought-provoking, or astonishing even, especially, if we consider that in the years to come the members of this line abandoned the Marian side and switched to Sulla. What caused this remarkable rise of the Valerii Flacci? There is no clear-cut answer to this exact question in the sources, so we can only speculate.

31 Gran. Lic. 35, 14-15Cr. T. R. S. Broughton, The magistrates..., vol. 2, pp. 51, 53.

32 C. M. Bulst, Cinnanum Tempus: A reassessment of the Dominatio Cinnae, "Historia" 1964 , Bd. 13, p. 320.

33 Ibidem, p. 316. See also F. Münzer, Baebia, in: RE, Supp. I, Aba bis Demokratia, Stuttgart 1903, col. 237.

34 It is interesting that in Rome there were two patrician consuls now. The second one was L. Cornelius Cinna. Apparently, it was decided that if there was already one plebeian consul chosen for $86 \mathrm{BC}-\mathrm{C}$. Marius - who managed to even hold his office, it would be fine if there were two patrician consuls for the rest of the year. See T. Corey Brennan, The praetorship..., p. 274, n. 53. Cf. however B. R. Katz, Caesar Strabo's struggle for the consulship and more, RhM 1977, 120, p. 55. See also C. Lanzani, Mario e Silla. Storia della democrazia romana negli anni 87-82 a.CR., Catania 1915, pp. 161-204. 
It is possible that what heavily influenced the change in the Valerii Flacci's fortunes was the death of $\mathrm{C}$. Marius. The relations between the Valerii Flacci and the seven-time consul were strong, as previously highlighted, and it cannot be refuted that this dead consul was the main reason they stayed on the Marian side. His death could have significantly weakened these relations. Cinna, by promoting the Valerii Flacci, could have wanted to create a stronger bond with them, and therefore with the ruling elite. He could also have had other reasons for doing so. He knew that the Valerii Flacci were an old patrician line with strong traditions, highly regarded by the elite of the Senate. The appointment of L. Valrius Flaccus as princeps senatus (even if the candidate himself was an obvious choice, since he was still an alive ex-censor, and maybe the eldest of the living consulares at that time) stands as hard evidence of this. There is not a lot that could be said about the Valerii Flacci's relations with other noble lines due to a lack of sources, but it seems like they remained on good terms with the Baebii and the influential Perpennae and Herennii. ${ }^{35}$

It cannot be denied that Cinna chose L. Valerius Flaccus as his partner in the consular office because of his personal abilities. It is known that the Flaccus's primary task was to command in the war with Mithridates. Even before his departure to the East however, maybe in February, right after the election for the consular office held on 5 February 86 BC, L. Valerius Flaccus passed a controversial bill at the popular assembly, known as lex Valeria de aere alieno. ${ }^{36}$

It stated that debtors were supposed to pay only one fourth of their debts to their creditors and the remaining part would be written off, provided that (but that was not noted explicitly in the sources) this one fourth of the debt was paid off immediately. ${ }^{37}$ Of course, the aim of this bill was to recover at least some of the debts incurred by the citizens, and to improve the financial situation of the crisis-ridden country. On the basis of Cic-

\footnotetext{
35 C. M. Bulst, Cinnanum tempus..., p. 320.

36 Cic., Font. 1; de off. 3, 20, 80; Quinct. 4, 17; Sall., Cat. 33; Vell. 2, 23,
} 2. G. Rotondi, Leges publicae populi Romani, Hildesheim 1962, pp. 347-348. More: H. Bennett, Cinna..., p. 40; M. Lovano, The age..., pp. 72-73.

37 C. M. Bulst, Cinnanum tempus..., p. 334. 
ero's information, a conclusion can be drawn that quaestors chose special registrars who would establish the paid-off and the written-off amounts. ${ }^{38}$ This bill was in force until the end of the Sullan restoration, until the time of the quaestorship of Titus Crispinus in 70 BC, ${ }^{39}$ but it may be assumed that it only applied to debts incurred before its entry into force (so before the year $80 \mathrm{BC}$ ). It is hard to say to what extent it improved the financial situation of the state, but it was met not only with understanding, but even the endorsement of the elite. It partially diffused tension within the society. On the one hand it allows those indebted to relax, and on the other hand it gave the creditors a chance to recuperate at least some of the money lent.

The next task given to the consul L. Valerius Flaccus was to command the war with Mithiridates. ${ }^{40}$ In this case Cinna was not guided by his colleague's military skills; the authors of the sources - who, it needs to be stressed, were not in favour of Flaccus in general - agree that he did not have any military experience. ${ }^{41}$ Instead, he had other advantages. The most important were his contacts in Asia. As previously mentioned, the Valerii Flacci governed this area in the nineties and they must have established a trade network there. ${ }^{42}$

The aim of Flaccus's mission in the East is described differently in different sources. Plutarch, for example, wrote that the war with the king of Pontus was only supposed to be an excuse, but the real reason was to start a war with Sulla who had fought with him ever since 88 BC. ${ }^{43}$ Of course, the implication made by the biographer from Chaeronea is not possible. Flaccus did not have enough armed forces (he had two legions against Sul-

38 Cic., Font. 1; Quinct. 17. M. Lovano, The age.., p. 73.

39 Cic., Font. 1.

40 Cic., Flacc. 61; Diod. 38, 8, 1; Strab. 13, 1, 27; 594c; Memn., FGrH 3B, 353, 34 Liv., Per. 82; Vell. 2, 24, 1; Plut., Sulla 20, 1; Luc. 7, 2; App., BC 1, 75, 346; Mith. 51-53; Cass. Dio 30-35, fr. 105, 1-5; Auct., Vir. Ill. 70, 1; Oros. 6, 2, 9. Por. Sall., Hist. 3, 33; 5, $13 \mathrm{M}$.

41 Liv., Per. 82; Oros. 6, 2, 9; Cass. Dio fr. 104. It cannot be denied that such a bad opinion about Flaccus's combat skills was influenced by Sulla's propaganda.

42 See Cic., Flac. 52, 55-59. See F. Santangelo, Sulla, the elites and the empire. A study of Roman policies in Italy and the Greek East, Leiden-Boston 2007, p. 65.

43 Plut., Sulla 20, 1. See E. Valgiglio, Silla a la crisi repubblicana, Firenze 1956, p. 34. 
la's experienced five) to be a danger of any kind to the future dictator. It is likely that the message of the biographer is tainted with Sulla's propaganda; it is also possible that Plutarch used Sulla's Commentarii at this point in his biography. ${ }^{44}$ Also, the idea of Flaccus going to the East as the commander to replace Sulla in the war is wrong, because nobody could possibly expect that Sulla would give up his command without a fight, considering that he did not recognise the law passed by the Senate to outlaw him and still considered himself the legal proconsul. ${ }^{45}$

The majority of ancient writers claim that Flaccus was sent to wage war against Mithridates, as contemporary researchers also agree. ${ }^{46}$ They stress that Cinna - who realised that Sulla was in Greece, so his hands were tied - sent Flaccus to Asia, so that he could prevail there and steal Sulla's thunder. ${ }^{47}$ The financial profits, which the departure to the East could have brought the Cinnans, were meaningful as well. The occupation of Asia by the Cinnans and thus Sulla's failure to subjugate this province made sourcing money from this affluent area possible. Taking advantage of Flaccus's contacts and his financial abilities could have boosted the financial resources of the public treasury, in this context.

Memnon of Rhodes wrote differently regarding the genesis of Flaccus's departure. He thought that the consul was sent to Asia to fight with Mithridates, but he had received instructions from the Senate beforehand, stating that before he took any action against the king of Pontus he would try to communicate with Sulla and, if possible, make an agreement with him to fight Mithridates together. If Sulla rejected the proposition of cooperating with Flaccus, then Flaccus would fight Sulla. ${ }^{48}$ This version recorded

44 T. J. Cornell (The fragments of the Roman historians, vol. 3, Oxford 2013, pp. 289299) does not associate this fragment of Sulla's biography with the dictator's Commentarii but the context of the text shows that such an identification is possible.

45 App., BC I, 73, 340; Mith. 51, 204. Cf. Mith. 60, 249. R. A. Bauman, The hostis declaration, "Athenaeum" 1973, vol. 61, pp. 289-292; H. Appel, Kontrowersje..., p. 158.

46 H. Bennet, Cinna..., pp. 45-46.

47 D. Magie, Roman rule in Asia Minor to the end of the first century after Christ, vol. 1, New Jersey 1950, p. 222.

48 Memn., FGrH 3B, 353, 34: 'The senate sent Valerius Flaccus and Fimbria to fight against Mithridates. It ordered them to share with Sulla in the war, if he cooperated with 
by Memnon is often undermined by contemporary researchers, who stress that Sulla could not have negotiated with Flaccus, since Sulla had been decreed an enemy by the Senate. ${ }^{49} \mathrm{It}$ is possible that Flaccus was entitled to cancel the decision of the Senate to outlaw Sulla. ${ }^{50}$ Moreover, we need to remember that in the next year the Senate already sent a delegation to Sulla in order to negotiate to make a settlement. It is known that the main advocate of dialogue with the future dictator was the princeps senatus, L. Valerius Flaccus, the consul of $100 \mathrm{BC} .{ }^{51}$ We cannot eliminate the possibility that the idea of negotiating with Sulla was born in the Senate before and spoken about for a while prior to L. Valerius Flaccus's departure to the East, and that he was the first person to probe the possibility of making an agreement with the outlawed proconsul.

Finally, Flaccus and Sulla never met in the East. There was a conflict in Asia between the Marian proconsul and the legate (or a quaestor) assigned to him, ${ }^{52}$ C. Flavius Fimbria. The background of this disagreement were differences in their attitude towards the discipline of soldiers in the army and the treatment of people from this province. It is enough to say that during the stay in Byzantium there was a revolt in Flaccus's army, due to which the proconsul needed to escape. He went to Asia, but he was caught in Nicomedia and killed by Fimbria's people. Fimbria took over command of the army and then sent his representatives to Rome with a demand to acknowledge him as the commander. The Senate was reluctant, but in the end the described conjuncture was accepted, and Fimbria was granted the imperium, which he most likely held as the proquaestor pro praetor. ${ }^{53}$

Although the death of the proconsul L. Valerius Flaccus, and then the lack of firm response from the Senate to Fimbria's lawlessness did not significantly change the political situation in Rome, it probably influenced

the senate, but if not, to make war against him first'.

${ }^{49}$ H. Bennett, Cinna..., pp. 45-46; M. Lovano, The age..., p. 105; Cf. however E. Badian, Waiting..., p. 56.

${ }_{50}$ Ch. Meier, Res publica amissa, Wiesbaden 1966, p. 233, n. 165.

51 Liv., Per. 83. E. Badian, Waiting..., p. 58.

52 T. R. S. Boughton, The magistrates..., vol. 3, p. 92.

53 A. Lintott, The offices of C. Flavius Fimbria in 86-5 BC, "Historia" 1971, Bd. 20, pp. 696-701. 
the Valerii Flacci's attitude towards Cinnans. L. Valerius Flaccus, the princeps senatus, gave a fiery speech in $85 \mathrm{BC}$, in which he argued for making peace with Sulla. This way, he took the lead of the peace-making faction in the Senate, which seemingly many senators were included in, since the Senate decided to start a dialogue with the proconsul. ${ }^{54}$ The peace talks were sabotaged by an extremist wing of Cinnans led by Cn. Papirius Carbon, and they were scrapped after Cinna's death in $84 . .^{55}$ After an unsuccessful attempt to compromise, war with Sulla was inevitable. In 83, the legions of the proconsul reached Italy and began their march on Rome. ${ }^{56}$

It is not entirely possible to tell how the death of L. Valerius Flaccus in the East and the abandonment of talks with Sulla influenced the position of the Valerii Flacci towards the Cinnans, who were in power. After he learned about the unsuccessful negotiations with Sulla, the princeps senatus disappeared from the historical sources, only to reappear as the magister equitum during Sulla's dictatorship. What happened to him during the war with Sulla is unknown. It can be assumed that he did not participate in the military campaign against Sulla, because if he had done so, his name would be on the list of proscribed adversaries. He was also not a proponent of Sulla in Rome - he would then have probably fallen victim to the prosecutions, to which Caius Marius the Younger subjected even the moderate senators in $82 \mathrm{BC}$, when L. Junius Damasippus, by order of the younger consul, killed P. Antistius, C. Papirius Carbon, P. Mucius Scaevola Pontifex and L. Domitius Ahenobarbus. ${ }^{57}$ The lack of L. Valerius Flaccus among these people is, for some researchers, proof of his fully pro-Marian stance. ${ }^{58}$ However, considering that only a few months later L. Valerius Flaccus appeared by Sulla's side, it can be assumed that he was simply not

54 Liv., Per. 83; App. BC 1, 77, 353. See B. W. Frier, Sulla's propaganda: The collapse of the Cinnan Republic, "American Journal of Philology" 1971, vol. 92, p. 592.

55 See T. Ładoń, Sulla's peace negotiations with Cinna's faction in 85-83 BC, in: Lucius Cornelius Sulla - history and tradition, eds. D. Słapek, I. Łuć, Lublin 2013, pp. 91-102.

56 T. R. S. Broughton, The magistrates..., vol. 2, p. 63.

57 Cic., Brut. 311; ND 3, 80; ad Fam. 9, 21, 3; Diod. 37, 29, 5; 38, 17, 1; Liv., Per. 86; Vell. 2, 16, 2-3; Val. Max. 9, 2, 3; Lucan 2, 126-129; Flor. 2, 9, 21; App., BC 1, 88, 403; Auct., Vir. Ill. 68, 2; Aug., De Civ. 3, 28-29; Oros. 5, 20, 4.

58 C. M. Bulst, Cinnanum tempus..., p. 322. 
in Rome during the Marian purge. This thesis is also consolidated by the absence of L. Valerius Flaccus in the capital in the first days after Sulla's victory; if he had been in Rome at that time, his presence there would have been noted by ancient writers because of the widely covered meeting of the Senate at the Temple of Bellona on 3 November 82 BC. ${ }^{59}$ It seems that in $82 \mathrm{BC}$ at the latest L. Valerius Flaccus either joined Sulla, or left Rome and waited in hiding for the raging war to end.

The attitude of L. Valerius Flaccus - the governor of Spain and Gallia Narbonensis - towards Cinna's party was becoming more and more conservative, lending credence to the thesis of a gulf between L. Valerius Flaccus with Cinnans after halting the negotiations with Sulla. It appears that his loyalty towards the Cinnan ruling elite began to waver immediately after the death of his brother Lucius in the East. It was Caius to whom the son of murdered Lucius escaped from Asia. ${ }^{60}$ The fact that he did not hide in Rome but went to his uncle in the province may mean that he did not feel safe in the capital. The attitude of Caius was at least ambiguous in certain aspects, too. Marcus Licinius Crassus, who was in Spain (ruled by Flaccus at that time) in $86 \mathrm{BC}$, needed to hide. One year later not only did he leave his hiding place, but he could also have had free rein to recruit for the army, which was supposed to help Sulla in the civil war. ${ }^{61}$ Gallia, governed by Caius Valerius Flaccus, became a safe place for some immigrants, who were escaping Italy due to the regime of Cinna. ${ }^{62}$ Apparently, they viewed this area as safe, and its governor as neutral at least.

The uncertain attitude of C. Valerius Flaccus did not escape the notice of the authorities in Rome. In $83 \mathrm{BC}$, a decision was made to take the governance of the Spanish provinces away from him. Q. Sertorius was

59 Cic., Rosc. Am. 153; Liv., Per. 88; Vell. 2, 27; Val. Max. 9, 2; Flor. 2, 9, 25; Plut., Sull. 30-31; App., BC 1, 95, 441; Cass. Dio, fr. 109, 5-9; Oros. 5, 21; Aug., De Civ. 3, 28. See T. Ładoń, Kilka uwag o posiedzeniu senatu w światyni Bellony 3 listopada 82 roku przed Chr., in: Elity w świecie starożytnym, ed. M. Cieśluk, Szczecin 2015, pp. 151-163.

${ }^{60}$ Schol. Bob. 96, 3-11St. Cf. Cic., Flacc. 63, 100. See C. F. Konrad, Plutarch's sertorius..., pp. 85-86.

61 Plut., Crass. 4, 1-6, 1.

62 E.g. for M. Caecilius Cornatus. See: App., BC 1, 73, 336; Plut., Mar. 43, 6. About him see F. Münzer, M. Caecilius Cornutus, in: RE, Bd. 3.1, Stuttgart 1897, col. 1200. 
appointed the new governor of these areas. The fact that Sertorius, unhindered by Flaccus, reached the Iberian Peninsula in $83 \mathrm{BC}$, cannot be evidence of Flaccus's loyalty towards the Marian party, but it is possible that he just did not wish to become embroiled in combat with Sertorius, who then most likely had one or two full legions by his side. ${ }^{63}$ The governance over Gallia Narbonensis was left to Caius, but thanks this his army was neutralised and pincered, which minimised the possibility of a revolt. ${ }^{64}$ At the same time, by leaving Gallia under his reign, Rome was still seen to trust him.

The Valerii Flacci became active in the first two months after Sulla's victory. This was especially visible in Lucius Valerius Flaccus's case, because when Sulla retreated from the city and called the Senate to appoint an interrex, the Senate chose L. Valerius Flaccus, hoping that he would spearhead the next consular election. However, Sulla sent a letter to the interrex, in which he ordered him to convince the Roman people to restore the dictatorship in Rome, which would last indefinitely until the situation within the Republic improved. Undoubtedly, Sulla wrote in the letter that he, himself, would be the best candidate for this office. Valerius Flaccus carried out Sulla's command and, at the popular assembly, he put a bill to the vote stating that he, as the interrex, appointed Sulla as dictator and himself the magister equitum. ${ }^{65}$

The office of magister equitum made Flaccus the second most important person in the country, immediately after the dictator. The fact that Flaccus was the princeps senatus undoubtedly helped him to achieve his promotion; nonetheless, choosing Flaccus was not a coincidence or a necessity but must have been Sulla's idea. First, the dictator knew that Flaccus used to be the leader of the moderate faction in the Senate, opted for dialogue with him and accepted his imperium in the East. Although he was involved with the Marians, he came from an old patrician family, which - from

63 T. Ładoń, Legiony rzymskie w Hiszpanii a kryzys Republiki w latach siedemdziesiątych I wieku przed Chr., "Zeszyty Historyczne Akademii im. Jana Długosza w Częstochowie" 2009, vol. 10, p. 18.

64 E. Badian, Studies..., pp. 89-90.

65 It is possible that Sulla, when he was the dictator, appointed Flaccus magister equitum. See F. J. Vervaet, The Lex Valeria..., p. $40 \mathrm{nn}$. 
Sulla's point of view, who was eager to promote patricians - was not meaningless. Flaccus was also one of few consulares still alive. By backing Sulla and acknowledging his imperium, he made an impression that there was a continuity of government maintained in the Republic. Finally, it is worth noticing that the previous demands of Sulla, as well as the laws established during his dictatorship, were backed by the authority of Flaccus from this point on.

Even if Sulla did not make public peace with the Valerii Flacci before the civil war, the appointment of L. Valerius Flaccus for the office of magister equitum formalised this alliance. Sulla was the dictator, of course, and the role of Flaccus was rather representative or propagandist; he was the executor of the dictator's orders, helped him rule and was his messenger in dialogue with the Senate. Nonetheless, the rise of the Valerii Flacci's power in the country in the first months of the dictatorship was certain. This is confirmed by the triumph granted to C. Valerius Flaccus for the victories in Spain during his governance there. ${ }^{66}$

The Valerii Flacci did not contribute to Sulla's victory in the First Civil War. They did not help him with their military power, nor were they repressed at the hand of his enemies. On the contrary, during the time of the dominatio Cinnae they held important offices in the state, so they could be seen as the representatives of the Marian party. However, they were moderate politicians, who on the one hand strove to make peace but on the other hand acted proactively for their own safety and benefits. The attitude of the Valerii Flacci in the eighties should be viewed in this way, and this was also the main reason they chose Sullas side, who, according to them, offered hope of ending the civil war, mending the Republic and restoring the superior role of the Senate in the country.

${ }^{66}$ Cic., Quinct. 28; Gran. Lic. 36, 5 Cr. 